\title{
MIRLET7F1 Pre-miRNA
}

National Cancer Institute

\section{Source}

National Cancer Institute. MIRLET7F1 Pre-miRNA. NCI Thesaurus. Code C82744.

MIRLET 7F1 pre-miRNA is an oligonucleotide that is encoded by the human MIRLET 7F1 gene and has a role in the regulation of gene expression. 